\title{
German Dissertations: The Present Situation
}

$I^{\mathrm{N}}$ 1941, the obligation to print German theses was suspended because of the war. As an alternative it was decided that six typewritten copies of theses were to be made, one copy of which was to remain at the faculty and five to be delivered to the respective university library. In 1951, pursuant to a recommendation of the Western German Librarians' Committee on Dissertations and Microfilms (Verein Deutscher Bibliothekare, Kommission für Dissertations- und Mikrofilmfragen; chairman, Dr. Bauhuis), it was decided to change the distribution of the five copies as follows: two copies to the respective university library (one of them for interlibrary loan or for the respective Landesbibliothek), one copy to the Deutsche Bibliothek at Frankfurt/ Main as Western German center, one copy to the Deutsche Bücherei at Leipzig as bibliographical center of all German dissertations, and one copy to the University Library at Berlin (East) as the historical collecting point for dissertations.

The university libraries of Eastern Germany send one copy of each dissertation through the University Library of Berlin (East) to the western center of dissertations at Frankfurt/Main. Unfortunately, not all Western German university libraries follow the recommended distribution, and therefore the Deutsche Bibliothek at Frankfurt/Main does not receive all German dissertations.

To make German typewritten dissertations of the past years available in the United States is a task worthy of further

Dr. Bauhuis is assistant director, Universitätis-Bibliothek, Heidelberg. consideration by American and German librarians. The question is to find funds for microfilming the unpublished dissertations, or a selection of dissertations, especially on the humanities. A film copy should perhaps be placed at the Library of Congress for interlibrary loan purposes.

On the other hand, American dissertations microfilmed by University Microfilms, Inc., and listed in its Dissertation Abstracts are not easily available to European library users. Imaginable perhaps would be a plan whereby German university libraries would send one copy of all printed theses to an American center such as the Midwest Inter-Library Center at Chicago, in exchange for which a film copy of all American theses microfilmed by University Microfilms, Inc., could be deposited in a German library.

These are sanguine plans for the future. For the present, when an American library wants a particular German dissertation, it should apply to the library of the university where the dissertation was made. It will then receive a copy of the dissertation when available, or a loan copy (through the international interlibrary loan service), or a microfilm made to order for the particular library.

At present there is a growing tendency to print the German theses. Any American library which wants to receive allor special fields of-dissertations of a Western German university now or in the future as the dissertations are printed should write to the respective university library. Already several German university libraries obtain 100 to 150 printed copies for exchange all over the world, especially with the United States, France, Holland, Switzerland, and the Scandinavian countries. 